\title{
The Role of Criminalistics Mentality and Fundamental Questions of Criminalistics in the Investigation
}

\author{
Dr. Endre Nyitrai, Ph.D. \\ Nemzeti Közszolgálati Egyetem \\ Hungary
}

\begin{abstract}
This study analyses the significance and raison of criminalistics thinking and the fundamental questions of criminalistics. Criminalistics and the defined principles and recommendations have an indispensable role in the understanding of the events of the past.
\end{abstract}

Key words: criminalistics way of thinking, fundamental questions of criminalistics, specific profiling, investigation, evidentiary measures

Successful combat against crime is inconceivable without criminalistics. One of the measures of the cognitive methods is the criminalistics attitude that is strongly connected to legal norms and based on the approach to understand the objective truth of the past and on the objective to establish material truth. ${ }^{1}$ Fundamental questions of criminalistics play a significant role in the comprehension of past events. ${ }^{2}$ Combat against crime must analyse the fundamental issues of criminalistics and the system of general statutory provisions jointly, since answering the fundamental questions of criminalistics largely assists both the investigation and the successful evidentiary procedures. Thinking is one of the forms of cognitive activities. Investigation, as a cognitive procedure is based on procedural regulations. The criminalistics way of thinking sees through investigation procedure, from the state of planning, during which members of the authority have to reconstruct the past event in theory, and they have to establish the objective truth upon casual connection between cause and effect. Understanding of truth is a multilevel process whereas the fundamental questions of criminalistics, raster investigation and evidentiary procedures have key importance in the cognizance of the relevant event.

JánosLakatos sees criminalistics thinking as one of the cognitive measures 'that is also a specific solution to the problems of investigation'?

Specific characteristics of the criminalistics way of thinking ${ }^{4}$ usually see through the investigation, which consists of the following components: reconstructive way of thinking based of legal norms, the application of versions, logical methods, intuition and phantasy, empathy, doubt, case-type skills, experience, collective wisdom self-assessment and coincidence.

In his study titled 'Brain efforts of criminal professionals. Theart and boundaries of criminalistics conclusions' Erich Anuschutrefers to the importance of logic besides 'experience' and 'simple common sense'. As for the criminalist without proper skills of logic the author states that he must surely be busy speculating on difficult cases, without any success guaranteed, unless coincidence or goodwill 'give him a hint'.

${ }^{1}$ Budaházi, Árpád, Polygraph Examinations. Blessing or Curse, 2005, Lap Lambert Academic Publishing, Saarbrücken, p. 5

${ }^{2}$ We must mention that the frames of the criminalistics way of thinking are continuously broadening with the development of sciences. Lately, several new scientific methods become part ofthe criminalistics attitude that were formerly unknown to this field. For example, let’s just refer to criminal geography. See more in Mátyás,Szabolcs (2018): A bünözésföldrajz vitás kérdései. Földrajzi Közlemények (Debated question of criminal geography, 2018, Geographical Announcements), Budapest, pp. 102-109

${ }^{3}$ BALla-Füszter,Erzsébet - LaKATOS,János:Kriminalisztika 1. A kriminalisztika egyes elméleti kérdéseCriminalistics 1., (Certain theoretical issues of criminalistics), 2012, Budapest, p. 57

${ }^{4}$ BaLla-Füszter, Erzsébet - LaKatos,János, Kriminalsiztika I. A kriminalisztika egyes elméleti kérdései(Criminalistics 1., Certain theoretical issues of criminalistics), 2012, Budapest, pp. 59-63

${ }^{5}$ HuAPtManN, Walter, A kriminalisztika aktuális kérdései, Tanulmányok öt európai országból. A kriminalisztika cselekvéstan egyes kérdései(Actual question of criminalistics, Studies from five European countries, Certain questions of criminalistics operation studies). 2001, Budapest, p. 110 
Elements of the criminalistics thoughts and the fundamental issues of criminalistics have an indispensable role both in the investigation and in the evidentiary procedure. Some theories suggest that issues of suspicion and reasonable suspicion are also parts of the criminalistics though. According to some approaches 'investigative thinking starts with the suspicion'.

These two definitions are connected to criminal procedures, however, several issues are raised in the course of the investigation, where such definitions do not even occur, not only they do not initiate the criminalistics way of thinking. ${ }^{6}$

Detection and comprehension of the event shall take place upon the series of theoretical actions, whereas the first phase is the hypothesis or supposition. Supposition is really an intermediate stage in the cognitive process that leads from notknowing to understanding. Nevertheless, practical skills, life experience and the application of the rules of logic are equally necessary for the supposition. In the phase of cognition these skills are not so well grounded that they could be the base of immediate determination of the consequences. Therefore, suppositions and consequences must be separated. ${ }^{7}$

Principle issues of criminalistics serve as special guidelines or a compass to point to the special skills and knowledge necessary for the understanding of the relevant event of the past. As of the number and the definition of the fundamental questions, scientific literature is still not uniform. The generally agreed classification is as follows:

- $\quad$ what happened?

- where?

- when?

- how?

- who?

- with whom?

- why? ? $^{8}$

According to Garamvölgyi' disposition, the principle questions of criminalistics start with the word: 'who?', 'what?', 'how?', 'with what?', 'where?', 'why?', 'with whom?'.In accordance with his grouping the questions 'what happened?', 'with what?', 'when?', 'where?', 'how ?' refer to the object or to the material side of the criminal act, while the questions 'why?', 'who?', 'with whom?' refer to the subject or to the personal side of the illicit action.

Generally, the principal questions of criminalistics can be complemented with the issue of fitting the case into a series of crimes - with regards to the modus operandi -, or in case of specific profile making, with the question 'what kind?' Instead of asking the principle criminalistics question of 'who?' the profiler is seeking the answer to the question 'what kind?' of the perpetration can be. (Finally, the profile will help to answer the question 'what kind?', while it is the task of the detective to answer the question 'who?'.) As of specific profile analysis, especially in cases of murder or sexual offenses the detective may complete the $7+1$ principle questions of criminalistics with the question 'what kind?', considering the fact that the perpetrator's personality, as an individual set of characteristics can be significantly conducive to the understanding of the past event and to the efficiency of the investigation. ${ }^{10}$

The profile is a method that helps and supports the investigation of criminal offenses where the perpetrator is unknown. ${ }^{11}$ The practice of this measure gains grounds in investigations alongside with the development of criminalistics, whereas a preliminary hypothesis is set up, regarding the persona of the perpetrator, answering the question, 'what kind of person could have committed the offence?', 'what his personality is like?'. Profiling can further narrow the scope of suspects, moreover, its results can be adapted in the implementation of the interrogation tactical

${ }^{6}$ BALLA-Füszter, Erzsébet - LAKATOS,János, Kriminalsiztika I. A kriminalisztika egyes elméleti kérdései(Criminalistics 1., Certain theoretical issues of criminalistics), 2012, Budapest, p. 61

${ }^{7}$ KATONA,GézaValós vagy valótlan? Értékelés a büntetőperbeli bizonyításban(Real or unreal? Evaluation in evidentiary procedure before court), 1990, Budapest, p. 42

${ }^{8}$ BALLA- LAKATOSin: as sited above pp. 63-65

${ }^{9}$ GARAMVÖLGYI,Vilmos, Kriminalisztikai alapkérdések, Rendőrségi Szemle 1962. (X. évfolyam) 4. sz., (Principle questions of criminalistics, Police Journal,Volume X. Issue 4.) 1962, Budapest, p. 322

${ }^{10}$ NyITRAI,Endre, Bünelemzés a nyomozásban, Pécsi Határör Tudományos Közlemények XVI. kötet, Modernkori Veszélyek Rendészeti Aspektusai (Crime analysis in the investigation, PécsBorder Patrol Scientific Announcements, Book XVI, Law Enforcement Aspects of Modern Age Dangers). 2015, Pécs, pp. 143-145

${ }^{11}$ GAMPEL, Andrea - SzÉKELY,György László, Bünelemzés a nyomozásban, Pécsi Határör Tudományos Közlemények XVI. kötet, Modernkori Veszélyek Rendészeti Aspektusai (Potentials of profiling in the Hungarian criminal procedures), p. 20

http://www.ugyeszek.hu/ftp/tartalom/ugyeszek_lapja/20095555/ul2009_kulonszam_all.pdf?phpMyAdmin=5e79130c4a2a40 8b3f002bed9c4d2fba (July 24, 2015) 
plan. During profiling, we do not name a specific person, but we describe the characteristics of the perpetration. From the aspect of the personal side, the objective of profiling is the specification of the perpetrator's characteristics in accordance with the acquired information.

The profile is information for the detective on the scope and range of persons amongst whom he should seek for the perpetrator, or in other words, who can be taken into account or included, since it is a form of a criminal analysis that can be used by the investing authority during its law enforcement activity quite quickly and effectively. The authority may gather information on the perpetrator's persona, on the best possible way of arresting him or on the best possible way of cooperation with the perpetrator during the procedure.

Profiling can be most effective if the perpetrator's psyche, social or cultural background has a strong influence on his motives, on the selection of the victim and on the actual method of commission. Practically, the investigation method of profile analysis should be applied in priority cases, where there are only a few traces that could provide information about the perpetrator. Profiling is most common in the investigation of serial offenses, especially in murder cases or sexual crimes. ${ }^{12}$ Sexual offenses and murder may be intertwined in case of serial killers, if antisocial personality disorders like sociopathic, psychopathic behaviour, necrophilia, cannibalism also describe perpetrators, therefore, these issues must be taken into consideration during the profile analysis. ${ }^{13}$ The aptitude for narcissistic personality disorder, the lack of empathy, the conspicuously devoted assistance towards the authority and following the breakings on the investigation - by the perpetrator -, moreover, the suffered childhood abuses may all be measures of a serial killer that should be taken into consideration during making the profile. ${ }^{14}$

Profile analysis may be implemented if physical abuse was part of conducting the criminal offense, or in case the victim and the perpetrator can somehow be related. When making the profile the analyst shall examine all relevant aspects of the case, furthermore, 'he will choose the closest and most similar cases, and by using a special computer program on the sampled cases, that focuses on statistic patterns and on the perpetrator's circumstances to narrow the range of possible offenders. Upon the above the profiler shall complete the profile that fits into the given case the most. ${ }^{15}$ The database used in profiling consists of more than 2000 detected cases of life threatening offenses. Approximately 1500 of these are completed homicide cases, while cca. 600 are attempted murder cases.

In the course of making the profile, the profiler shall study the minutes taken at the on-site survey, the coroner's report or the medical expert opinion, the photos taken at the site and shall examine the criminal site. Finally, the profiler shall complete his opinion on the grounds of the database and his own impressions on the case.

To sum it all up, we may state that consideration of the criminalistics way of thinking and the principle questions of criminalistics may assist detection, evidentiary procedures and may increase the efficiency of the investigation. Scientific and technical developments enhance the application of new measures and the processing of results. Answering fundamental questions of criminalistics may give grounds to the execution of investigative or law enforcement operations, whereas criminalistics way of thought is continuously present.

\section{Bibliography}

BALLA-Füszter, Erzsébet - LAKATOS,János, Kriminalisztika 1. A kriminalisztika egyes elméleti kérdése(Criminalistics 1., Certain theoretical issues of criminalistics), 2012, Budapest, pp. 57-63

Budaházi, Árpád, Polygraph Examinations. Blessing or Curse, 2005, Lap Lambert Academic Publishing, Saarbrücken, p. 5

HuAPTMANN, Walter, A kriminalisztika aktuális kérdései, Tanulmányok öt európai országból. A kriminalisztika cselekvéstan egyes kérdései(Actual question of criminalistics, Studies from five European countries, Certain questions of criminalistics operation studies). 2001, Budapest, p. 110

\footnotetext{
1213/2001. (X. 2.) ORFK utasítása A Magyar Köztársaság Rendőrsége Bünelemzési Szabályzatának kiadásáról(13/2001. (X. 2.) ORFK order on issuing the Regulation of criminal analysis of the Police of the Hungarian Republic)

${ }^{13}$ Ürmös Simon, Gabriella, The traits and the thrill of serial killers. Internal Security, Volume 7, Issue 2. WyzszaSzkolaPolicji w Szczytnie (Police Academy Szczytno) 2015, p. 35 (pp. 33-42)

${ }^{14}$ Ürmös Simon, Gabriella, The portrayal and the attributes of serial killers and the most notorious ones. Internal Security. WyzszaSzkolaPolicji w Szczytnie (Police Academy Szczytno), 2018 (under publishing)

${ }^{15}$ NAGY,Enikő - ELEKESLenhardt, Zsuzsa, A specifikus elkövetői profilalkotás elmélet és gyakorlata, Belügyi Szemle, BM Kiadó, Budapest, 2004/6., 52. évfolyam(Theory and practice of specific perpetrator profiling, Journal of Internal Affairs, BM Publishing, Volume 52, 2004/6), Budapest, p. 55
} 
KATONA,GézaValós vagy valótlan? Értékelés a büntetőperbeli bizonyításban. (Real or unreal? Evaluation in evidentiary procedure before court), 1990, Budapest, p. 42

GAMPEL, Andrea - SzÉKELY,György László, A profilalkotás alkalmazásnak lehetőségei a magyar büntetőeljárásban(Potentials of profiling in the Hungarian criminal procedures), p. 20

GARAmVÖLGYI,Vilmos, Kriminalisztikai alapkérdések, Rendőrségi Szemle 1962. (X. évfolyam) 4. sz., (Principle questions of criminalistics, Police Journal, Volume X. Issue 4. 1962), Budapest, p. 322

Mátyás, SzabolcsA bünözésföldrajz vitás kérdései. Földrajzi Közlemények(Debated question of criminal geography, 2018, Geographical Announcements), Budapest, pp. 102-109

NYITRAI,Endre, Bünelemzés a nyomozásban, Pécsi Határőr Tudományos Közlemények XVI. kötet, Modernkori Veszélyek Rendészeti Aspektusai. (Crime analysis in the investigation, Pécs Border Patrol Scientific Announcements, Book XVI, Law Enforcement Aspects of Modern Age Dangers.) 2015, Pécs, pp. 143-145

Ürmös Simon, Gabriella, The traits and the thrill of serial killers. Internal Security, Volume 7, Issue 2. WyzszaSzkolaPolicji w Szczytnie (Police Academy Szczytno) 2015, p. 35 (pp. 33-42)

Ürmös Simon, Gabriella, The portrayal and the attributes of serial killers and the most notorious ones. Internal Security. WyzszaSzkolaPolicji w Szczytnie (Police Academy Szczytno), 2018 (under publishing)

NAGY,Enikő - ELEKESLenhardt, Zsuzsa, A specifikus elkövetői profilalkotás elmélet és gyakorlata, Belügyi Szemle, BM Kiadó(Theory and practice of specific perpetrator profiling, Journal of Internal Affairs, BM Publishing, Volume 52, 2004/6), Budapest, p. 55

http://www.ugyeszek.hu/ftp/tartalom/ugyeszek_lapja/20095555/ul2009_kulonszam_all.pdf?phpMyAdmin=5e79130c4a 2a408b3f002bed9c4d2fba (July 24, 2015)

13/2001. (X. 2.) ORFK utasítása A Magyar Köztársaság Rendőrsége Bünelemzési Szabályzatának kiadásáról (13/2001. (X. 2.) ORFK order on issuing the Regulation of criminal analysis of the Police of the Hungarian Republic) 